\author{
Agro-Science Journal of Tropical Agriculture, Food, Environment and Extension \\ Volume 10 Number 1 January 2011 pp. $72-79$ \\ ISSN 1119-7455
}

\title{
EFFECT OF CLIMATE CHANGE ON THE FOOD SUPPLY SYSTEM: IMPLICATIONS FOR FOOD PROCESSING IN NIGERIA
}

\author{
Enwere N. J. and Ani J. C. \\ Department of Food Science and Technology \\ University of Nigeria, Nsukka, Nigeria
}

\begin{abstract}
Climate change has become an issue of great concern in recent years due to its effect on every aspect of life. The ecosystem, agriculture, industry, households and human well-being are all intertwined with climate change issues. The food supply system worldwide has been affected and is also contributing to climate change due to emission of greenhouse gases that results in global warming with its attendant consequences such as floods, drought, forest fires, poverty, malnutrition, health and various socioeconomic problems. Agriculture and food processing, preservation, storage and distribution activities are seriously affected leading to adverse effect on the food supply chain. Holistic global, regional and national policies are required to cope with effects of global warming in such a way as to build people's resilience and that of food supply.
\end{abstract}

\section{INTRODUCTION}

Increase in average global temperatures usually referred to as climate change or global warming has been observed for many decades. This is caused primarily by increases in greenhouse gases generated by various activities. Climate change or global warming has become a reality, with such adverse effects as disruption of seasonal cycles, ecosystems; agriculture, water needs and supply, and food production. It also leads to increase in sea-level with its attendant consequences, harsh weather, increased frequency and intensity of storms, floods, hurricanes, droughts, increased frequency of forest fires, poverty, malnutrition and series of health and socio-economic problems. Various studies have shown that natural events and human activities have contributed to an increase in average global temperatures (BNRCC, 2008).

Climate change has emerged as a major threat to food security, and FAO has rightly opined that governments need to find "creative solutions" and "alternative approaches" to deal with the challenge. Evidently changes in the air temperature and rainfall, as well as more frequent floods and droughts will have long-term effects on the viability and productivity of world agroecosystems (Heller, 2007).In anticipation of these challenges therefore agricultural systems need to be adapted to the changed conditions and specific stresses. One way of doing this would be to introduce crop varieties that can tolorate heat and water stress and also adapt innovative methods of processing, storage, transportation, and distribution of existing and emerging food crops.

While dealing with the causes of climate change - by reducing emissions and increasing greenhouse gas sinks - it is crucial to also take immediate action to cope with its effects. Ways must be found to build up peoples' resilience as well as that of food production, processing, preservation, distribution, transportation and storage systems which are major contributors to greenhouse gasses. Such measures as discouragement of the use of fossil fuel powered plants by mega industries and encouragement of small scale industries to reduce transportation with its attendant energy waste could be adapted. According to FAO, agriculture is both the culprit and the victim when it comes to climate change though the impacts on crop production are not geographically evenly distributed (Fischer et al., 2002). For example, the livestock sector is thought to account for 18 percent of global greenhouse gas emissions, while deforestation is responsible for 18 percent of carbon dioxide emissions. According to a study published in 2007 in the Journal of "Environmental Research Letters", warming temperatures have caused annual losses of roughly 
\$5bn for major food crops (Heller, 2007). In addition to crop failure, pests and crop disease causing agents in Nigeria for instance migrate in response to climate variations and pose a threat to livestock in other parts of the country where the effects are less drastic.

The objective of this paper is to review information on climate change as it affects food processing and food supply system in Nigeria.

Although agriculture itself is responsible for only about a quarter of the energy used to get food to our tables, the real waste of energy and the pollution happen in the broader international food systems: the processing, packaging, freezing, cooking, and moving of food. Much of this tremendous global waste and destruction could be avoided if the food systems were decentralized and agriculture tilt more towards local and regional markets. Small farmers and consumers would get closer together again, and large agribusiness would be cut out of the food system. Healthier food, happier producers and consumers, and a sustainable planet would be the result.

\section{Effect of Climate Change in Nigeria}

Nigeria is experiencing adverse climate conditions with negative impacts on the welfare of millions of people, (Medugu, 2009). Persistent droughts and flooding, off season rains and dry spells have sent growing seasons out of orbit, in a country that is dependent on rain fed agriculture. Alarm bells are ringing with lakes drying up and a reduction in river flow in the arid and semi arid regions. The result is fewer water supplies for use in agriculture, food processing and preparation, hydro power generation and other uses. Africa will be worst hit by the effects of climate change and Nigeria is part of it.

The agricultural sector contributes some percentage of the Nigerian Gross National Product and majority of the rural populace are employed in this sector. The impact of climate change can be vast. In Nigeria, this means that some stable ecosystems such as the Sahel Savanna may become vulnerable because warming will reinforce existing patterns of water scarcity thus increasing the risk of drought both in Nigeria and in most countries in West Africa. The country's aquatic ecosystems, wetlands and other habitats will create overwhelming problems for an already impoverished populace (BNRCC, 2008).

In a preliminary study conducted by the Intergovernmental Panel on Climate Change (IPCC) on the vulnerability of various sectors of the Nigerian economy to Climate Change, the seven natural and human systems identified were condensed into five systems viz:

* Human settlements and health;

- Water resources, wetlands, and

freshwater ecosystems;

- $\quad$ Energy, industry, commerce, and

financial services;

- $\quad$ Agriculture, food security, land

- degradation, forestry, and biodiversity; and

- $\quad$ Coastal zone and marine ecosystems.

According to the study, virtually all the sectors analyzed manifested some evidence of vulnerability to climate change. None was unaffected, nor will remain unaffected in future by changes to climatic conditions (IPCC, 2007).

Based on the IPCC projections, the humid tropical zone of southern Nigeria, which is already too hot and too wet, is expected to be characterized by increase in both temperature and precipitation, especially at the peak of the rainy season. Already, temperature increases of 0.2 degree to 0.3 degree per decade have been observed in the various ecological zones of the country, particularly since 1960s. Data from the environment watchdog reveal that for the humid zones of Nigeria, precipitation increases from about two to three per cent for each degree of global warming may be expected. By implication, it is expected that precipitation will probably increase by approximately 5 to 20 percent in the very humid areas of the forest regions and the southern savannah areas.

\section{Food Supply and Climate Change}

According to Heller (2007), researchers at the Carnegie Institution and Lawrence Livermore National Laboratory reported that from 1981 to 2002, global warming reduced the combined production of wheat, corn, and barley - grains that form the foundation of much of the world's diet by $40 \mathrm{~m}$ metric tons per year. On the average, global yields for several of the crops dropped by about three to five percent for every one degree $\left({ }^{0} \mathrm{~F}\right)$ increase in temperature and average global temperatures increased by about 0.7 degrees ${ }^{0} \mathrm{~F}$ during the study period, with even larger changes in several regions. Odeh (2008) reported that fish stocks off the coast of Nigeria are already threatened by the changing sea temperature and acidity caused by temperature increases.

With rising concerns about climate change, many people are looking for ways to reduce their environmental impact. The most prominent ideas include choosing energy-efficient light bulbs, driving hybrid cars, installing solar 
panels and changing our food habits - a step we can take every day. Given that agriculture is re: Enwere N. J. and Ani J. C. rd of global warmming gases woriuwiue, anlu most agricultural activity is food-related, the significant impact of our food choices can hardly be ignored (United Nations, Food and Agriculture Organization, 2001). The primary goal of Bon Appétit's Low Carbon Diet program is to raise awareness of the significant connection between the food system and climate change, and to activate chefs and consumers to make responsible choices.

\section{Green House Gases and the food supply chain}

It has been reported (WRI, 2006) that the modern food supply system (growing, fishing, processing, transporting, preparing, packaging, and disposing) contribute abundant amounts of four of the six principal greenhouse gases that create the "greenhouse effect." These gases are carbon dioxide $\left(\mathrm{CO}_{2}\right)$, methane $\left(\mathrm{CH}_{4}\right)$, nitrous oxide $\left(\mathrm{N}_{2} \mathrm{O}\right)$ and chlorofluorocarbons (CFCs) (WRI, 2006).

\section{Carbon dioxide}

The most abundant and commonly-known greenhouse gas, carbon dioxide, comes from burning fossil fuels to transport our food by plane, truck, rail, car or boat. The energy used to process, package, heat or chill food-are also significant sources of $\mathrm{CO}_{2}$ emissions. Carbon dioxide has a global warming potential of 1 million metric tons (EPA, 2009).

\section{Methane}

Although carbon dioxide is the 'baseline' greenhouse gas, methane gas is critically important because it is 23 times more potent at trapping heat on the earth's surface than $\mathrm{CO}_{2}$. The food supply system is responsible for a tremendous portion of all methane produced worldwide. Cows and other ruminants (e.g., sheep and goats) are the largest single source of methane emissions in the United States (Eshel and Martin, 2006). A second source of methane in our food system comes from food waste in landfills. People frequently dispose the leftovers on their plates thinking it's natural and biodegradable without realizing that organic matter (primarily food scraps) in a landfill contributes to methane gas production (Intergovernmental Panel on Climate Change, 2007). According to the United States Environmental Protection Agency report of 2006, Nigeria ranked $9^{\text {th }}$ in the emission of methane green house gas in the world.

\section{Nitrous Oxide}

Nitrous Oxide $\left(\mathrm{N}_{2} \mathrm{O}\right)$, which is 300 times more potent than $\mathrm{CO}_{2}$, is emitted by bacteria in soils and oceans, but agricultural practices (cultivating soil, over-using nitrogen fertilizers, and handling animal waste) are sources of humanproduced nitrous oxide that stimulate naturally occurring bacteria to produce more nitrous oxide. The livestock sector (primarily cows, birds, and pigs) produces $65 \%$ of nitrous oxide, and crop agricultural processes contribute another $15 \%$ of all human-related sources. Chlorofluorocarbons (CFCs) have been used in refrigeration, air conditioning, and as solvents but are now known to be one of the main contributors to ozone depletion (United States Environmental Protection Agency, 2007).

\section{Contribution of greenhouse gases by the food industry Food Processing}

Besides greenhouse gas emissions from agriculture and deforestation, the food supply system also produce greenhouse gases during processing and manufacturing. Most of these emissions come from energy use. Using energy causes the release of the greenhouse gas carbon dioxide. This gas is emitted when fossil fuels are burnt to produce energy. The contribution of various sectors in the food supply chain to green house emission in the United Kingdom is shown in Fig. 1. The data for Nigeria is not currently available. With growing interest and concern for the effect of climate change in Nigeria, such data may become available in the near future. 


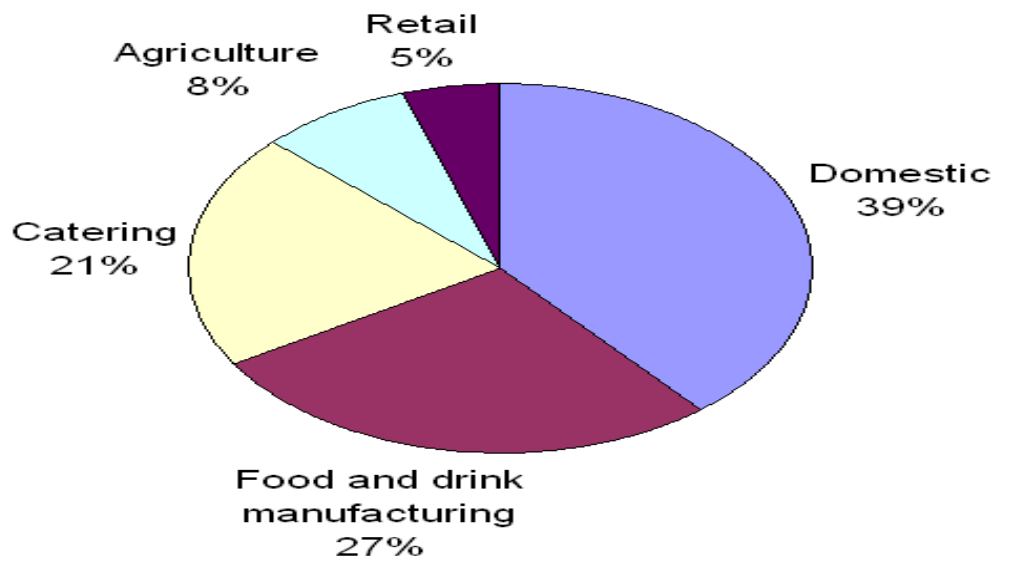

Fig.1. The proportion of primary energy used during the different stages of food production (excluding transportation)

in the UK.

Source: DEFRA (2006).

Changes in the way we cook and preserve our food can have a significant impact on emissions as a large proportion of emissions are from energy we use in our homes when cooking and refrigerating food. But the food and drink manufacturing, food retail and catering sectors are currently responsible for approximately $4 \%$ of the UK's annual greenhouse gas emissions, so it is vital that industry plays its part too (Food Industry Sustainability Strategy Champions' Group, 2000). The food industry in Nigeria, therefore contributes to this but not as much as the developed countries.

Food and drink manufacturers can help curb carbon dioxide emissions by reducing the amount of energy they use. A possible mitigation alternative may be the use of solar and domestic wastes as energy sources. So far food manufacturers are having mixed success at doing so. They have managed substantial cuts in energy use by improving efficiency, although some of their progress has been cancelled out by the drive to increase productivity (Food Industry Sustainability Strategy, 2000). But they will still have to increase their efforts if they are to reach their carbon dioxide emission reduction targets which is currently set at 20 per cent by the Government's Food Industry Sustainability Strategy (2006).

To achieve this it has been suggested that more research is needed to determine which areas of manufacturing are most wasteful. Sectors such as meat and dairy processing have already been identified as the most wasteful in terms of energy consumption (Food Industry Sustainability Strategy, DEFRA, 2006). Some processed food such as ready-meals are also particularly energy demanding because they have to be cooked and cooled more than once, thereby adding to both the manufacturing and domestic emissions.

\section{Food refrigeration}

Refrigeration has been identified as an area where dramatic emission cuts could be made relatively easily, by using and maintaining energy-efficient equipment correctly. This would be an important step to take because food refrigeration is estimated to account for up to 3.5 per cent of the UK's greenhouse gas emissions (International Institute of Refrigeration 2003; Food Climate Research Network, 2007). One of the reasons for this being so high is the shift in our food culture and tastes .For example, increased storage and consumption of refrigerated and frozen fresh and processed foods and chilled drinks has increased refrigeration needs. Similarly has our desire to eat large amounts of meat and dairy - the food products that require the most refrigeration throughout their lifecycle, and therefore generate the most carbon dioxide emissions through energy use. A mitigation strategy would involve reduction of low temperature preservation/chilling/freezing of foods and cold chain distribution to save energy.

\section{Retail}

Shops and supermarkets and shopping malls which vend frozen and refrigerated foods and drinks contribute substantially to green house emissions. Shops and supermarkets in particular - are also responsible for a lot of the traffic on our roads, which also has an impact on climate change. Use 
Enwere N. J. and Ani J. C.

of increase mass transit railways/metroline systems may impact positively on green house emission.

\section{Transportation}

Food miles are now talked about by everyone from shoppers to retailers and the media. Crops and animals are shipped, driven and flown to factories, food is transported to shops and then we drive to the supermarket to buy it - but what impact does this actually have?

Food transport accounts for one quarter of all heavy-goods vehicle miles in the UK. Around one in ten car journeys are for food shopping. Although most of us could walk to the shops to buy basics like bread and milk, many of us don't. The food miles 'wasted' on unnecessary car journeys are thought to be the equivalent of over half a million transatlantic flights a year (DEFRA, 2005; Department of Transport, 2007; Future Foundation, 2007).

First, food and feed are being imported and exported all over the world much more than ever before. The fact that fewer, larger companies are supplying is also contributing to the problem. Changes in retail are also responsible. The rise of the supermarkets means that more food has to go through regional distribution centres, mainly travelling by heavy-goods vehicle. We have also changed our shopping patterns. We have gone from making frequent trips on foot to local shops to weekly car trips to out-of-town supermarkets, topped up by further car trips for essentials like bread and milk throughout the week. Farmers and the environment can benefit from relying on local and regional markets rather than on global markets so as to reduce emission of green house gases and their contribution to global warming.

\section{Effect of Climate Change on Food Safety}

Climate change may have both direct and indirect impact on the occurrence of food safety hazards at various stages of the food supply chain. These changes have implications for food production, food security and food safety. Climate change impacts not only on primary production but also on food manufacturing and trade. Emerging hazards in primary production could influence the design of the safety management systems required to effectively control those hazards and ensure the safety of the final product. Furthermore, increasing average temperatures could increase hygiene risks associated with storage and distribution of food commodities. It is important, therefore, that the food industry be vigilant to the need to modify hygiene programmes as a result of climate change.
Reduced availability and quality of water in food handling and processing operations arising from floods and drought will also give rise to new challenges to hygiene management. It is anticipated that these risk management measures and adaptation strategies will pose greatest challenge for developing countries such as Nigeria. Evidence of the impact of climate change on the transmission of food and waterborne diseases comes from a number of sources, e.g. the seasonality of food borne and diarrhoeal diseases, changes in disease patterns that occur as a consequence of temperature, and associations between increased incidence of food and waterborne illness and severe weather events (Hall et al., 2002; Rose et al., 2001).

There are a number of other more speculative potential impacts of global climate change on food safety. These include:

i) impacts on microbial evolution and stress response;

ii) pathogen emergence;

iii) changes in water availability and quality; and

iv) other considerations.

Over the course of time, many bacterial agents have developed mechanisms that allow them to survive and even grow under unfavourable or "stressful" conditions. Many of these conditions are manipulations of the same intrinsic and extrinsic parameters described above. Stress responses are encoded genetically and in many cases, initial exposure to a sub-lethal dose of a stressor will "condition" the bacterial cell, allowing it to survive even harsher conditions provided by that stressor, where, for instance, the organism is able to survive an acid shock as low as $\mathrm{pH} 2$ after previous exposure to $\mathrm{pH} 5$. In addition, as microorganisms acquire increased tolerance after pre-exposure to a sublethal stress, they frequently develop enhanced resistance to other types of stress, a phenomenon referred as cross-protection (Rodriguez-Romo and Yousef, 2005). This is relevant to global climate change in that climate-induced changes in intrinsic factors may induce stress responses that make certain bacteria more resistant. Climatic change can also impact the emergence or re-emergence of food borne pathogens and infectious disease agents. Emerging food borne pathogens are defined as infectious agents, transmitted by food borne routes, which have (i) newly appeared in a population; (ii) were thought to be controlled but are now resurging; or (iii) have existed but are rapidly increasing in incidence, geographic range, or by some other factor. Also included in this 
definition are agents for which a food borne route of transmission has been identified only recently.

Rarely, if ever, do food borne pathogens emerge without a reason. There are some general principles of pathogen emergence, which are associated with changes in the following sectors: (i) ecology and agriculture; (ii) technology and industry; (iii) globalization; (iv) human behaviour and demographics; (v) epidemiological surveillance; and (vi) microbial adaptation (Tauxe, 2002). It is important to recognize that pathogen emergence usually occurs as a consequence of a combination of two or more specific factors.

Periods of excessive precipitation and drought can influence both the availability and the microbiological quality of water. Furthermore, new demands on existing water sources could occur if sea levels rise as predicted, adversely impacting on water availability (Charron et al., 2008). An emerging environmental health threat is the decline in global freshwater resources caused mostly by increasing rates of water extraction and contamination. This has resulted in a decline in both water quality and quantity, especially in arid regions such as the Mediterranean and Northern Africa (Campbell-Lendrum et al., 2006). It is a well known fact that limited access to safe water has a negative effect on hygiene practices throughout the food chain.

There are many other potential impacts of global climate change on food safety. For example, climate change could result in movement of crop production areas, resulting in very different ecosystem exposures, including microbes, pests (insects), and wild animals (rodents, reptiles and amphibians). Intermingling or crowding of food animals caused in response to natural disaster or climate induced changes in animal husbandry practices might promote the transmission of pathogens between animals, resulting in greater pathogen load in faeces and increased prevalence of carcass contamination. Nonetheless, there are a few characteristics of pathogens that may predispose them to being more sensitive to the impacts of global climate change. For example, those food borne pathogens that cause disease at very low doses (enteric viruses, parasitic protozoa, Shigella spp., enterohemorrhagic E. coli strains) and/or have notable environmental persistence (enteric viruses and parasitic protozoa) will likely be of great concern, particularly after adverse weather events. Those pathogens with documented stress tolerance responses (temperature and $\mathrm{pH}$ ), such as enterohemorrhagic E. coli and Salmonella are likely to compete better in the event of climate change.
Food Processing in Nigeria under Climate Change Conditions

Nigeria is not immune to climate change, so also is its food and drink industries and its kitchens. Reduction in food production, changes in quality and quantity of foods and the characteristics of the natural microflora of food stuffs and environment, water quality and availability poses great challenges to food processing in Nigeria. There is need to study the climate change issues and determine how best to integrate it in the Nigerian situation. Processing methods and machinery may need to be modified to process new raw materials, probably coming from new and unusual sources and with unusual composition and characteristics. Global warming is inimical to food processing as it has a great potential to reduce agricultural production thus limiting raw material supply to food processing industries and making the objectives of the industry unattainable .Food manufacturing activities should utilize innovative methods that minimize the impact on the environment, water use, greenhouse gas emissions, waste generation, and energy requirements. Food manufacturers who respond effectively to climate change will have the advantage of being at the forefront of a new consumer trend which is "sustainably manufactured foods". Responding to increasingly environmentally-conscious consumers as well as reducing environmental impact and operational costs are just some of the benefits of "sustainable manufacturing". Sustainably manufactured foods are becoming as important to consumers as healthy, convenient, high quality and 'fresh' foods. Other benefits include greater understanding of the threat of climate change to food security and the risks to future supply chain, improved management of inputs and outputs, development of sustainability strategies such as process control/optimization, waste recycling for energy production and water minimization/reuse strategies. With greater understanding, food processors in Nigeria are more likely to take appropriate steps to mitigate the effect of climate change on the food supply chain through responsive and responsible food processing activities 
Enwere N. J. and Ani J. C.

\section{CONCLUSION}

The effect of climate change on food production and processing should be of concern to food processors in Nigeria. Floods, drought and high temperature create changes in the ecosystem that affect agricultural activities which are the bedrock of Nigeria's food supply chain and this invariably impacts adversely on food processing and security. Climate change has both direct and indirect impacts on the occurrence of food safety hazards at various stages of the food supply chain. Since safety of the consumer is of utmost importance in any food supply system, it is necessary for the government to initiate adaptive measures to cope with challenges arising from climate change, especially identifying emerging food safety risks that are linked to climate change.

\section{REFERENCES}

Building Nigeria's Response To Climate Change (BNRCC), (2008). 1, Oluokun Street, Bodija, U.I. P.O. Box 22025, Ibadan, NIGERIA. email: info@ nigeriaclimatechange.org

Campbell-Lendrum D, Corvalan C, Neira M (2007). Global climate change: implications for international public health policy. Bull. WHO 85:235-237.

Casey J. W. and Holden N. M. (2005). Greenhouse Gas Emissions from Conventional, Agricenvironmental Scheme, and Organ SucklerBeef Units.

Charron DF, Thomas MK, Waltner-Toews d, Aramini JJ, Edge T, Kent RA, Maarouf AR, Wilson J (2004) Vulnerability of waterborne diseases to climate change in Canada: a review. J. Tox. Environ. Health. 67:1667-1677.

Charron DF, Thomas MK, Waltner-Toews d, Aramini JJ, Edge T, Kent RA, Maarouf AR, Wilson J (2004) Vulnerability of waterborne diseases to climate change in Canada: a review. J. Tox. Environ. Health. 67:1667-1677.

DEFRA ( 2005).The validity of food miles as an indicator of sustainable development.

DEFRA, (2006). Environmental Impacts of Food Production and Consumption, Food Industry Sustainability Strategy , http://www.defra.gov.uk/science/project_ data/DocumentLi

DEFRA,(2006). Food Industry Sustainability Strategy, http://www.defra.gov.uk/science/project_ data/DocumentLi

Department of Transport (2007). Personal Travel Factsheet. Energy Consumption in the UK,DTI,

http://www.berr.gov.uk/files/file11250.pd Food Industry Sustainability Strategy

EPA (2009). Environmental protection agency (EPA). Glossary of climate change terms. Eshel, Gidon and Martin, Pamela. Diet, Energy and Global Warming, Earth Interactions, 10:1-17; 2006.

Fischer, G., Shah, M, Velthuizen, H. (2002). Climate change and agricultural vulnerability 11ASA Publ.

Food Climate Research Network. (2007). Food refrigeration: What is the contribution to greenhouse gas $=$ emissions and how might emissions be reduced? http://www.fcrn. rg.uk/frcnresearch/publications/PDF

Food Industry Sustainability Strategy Champions' Group (2000). Final submission of the on Energy and Climate Change, May 2000, brary/EV02007/EV02007_4601_FRP.pdf

Future Foundation (2007). Local Life report: Shopping miles,

Hall GV, D’Souza RM, Kirk MD (2002.) Foodborne disease in the new millennium: out of the frying pan and into the fire? Med. J. Aust. 177:614-618.

International Institute of Refrigeration ( 2003). How to improve energy efficiency in refrigerating equipment', s/FCRN\%20refrigeration\%20paper\%20fi nal.pdf

IPCC (Intergovernmental Panel on Climate Change) (2007) "Summary for Policymakers." In Climate Change 2007: Impacts, Adaptation and vulnerability. Contribution of Working Group II to the Fourth Assessment Report of the Intergovernmental Panel on Climate Change, M.L. Parry, O.F. Canziani, J.P. Palutikot, P.J. van der Linden, and C.E. Hanson, eds. Cambridge, UK: Cambridge University Press.

Islam M.R, Jahiruddin M, Rahman GKMM, Miah MAM, Farid ATM, (2007). Understanding Food Waste. Waste Resources and Action Programme, Oxford, United Kingdom, 2007. Lorraine Heller, (2007), Decision News Media.

Medugu, N. I. (2009). The Effects of Climate Change in Nigeria 
Nwosu, K. I. (2010). Climatic Change, Energy and Environmental Sustainability: Impact On Food Production, Processing And Storage. Paper presented at the $34^{\text {th }}$ Annual Conference held in Port Harcourt from October 18-22, 2010.

Odeh, O. (2008). Climate change threatens fishstocks. Daily independent Lagos, independent press Ltd, pc8

Rodriguez-Romo L, Yousef, A (2005). Crossprotective effects of bacterial stress. In M. Griffiths (ed.), Understanding Pathogen Behaviour. Woodhead Publishing, Cambridge, U.K.

Rose JB, Epstein PR, Lipp EK, Sherman BH, Bernard SM, Patz JA (2001). Climate variability and change in the United States: potential impacts on water- and foodborne diseases caused by microbiologic agent. Environ. Health Perspectives, 109:211-221.
Steinfeld H.; Gerber, P.; Wassenaar, T.; Castel, V.; Rosales, M. and de Haan, C. (2006). Livestock's Long Shadow: Environmental Issues and Options. Food and Agriculture Organization of the United Nations, pp $99-100$.

Tauxe, R.V (2002). Emerging foodborne pathogens. Int. J. Food Microbiol. 78, 3141.

Transport (2003). Wise Moves: Exploring the relationship between food, transport and $\mathrm{CO} 2$,

United Nations, Food and Agriculture Organization (2001). Climate Variability and Change: A Challenge for Sustainable Agricultural Production.

United States Environmental Protection Agency (2007). Inventory of U.S. Greenhouse Gas emissions and Sinks: 1990-2005.

WRI (2006). Greenhouse Gases and Where They Come From, http://www.wri.org/climate/ $\underline{\text { topic_content.cfm?cid }=4177}$ 